\title{
Weaving networks: therapeutic itineraries of people with ostomy
}

\author{
Tecendo redes: itinerários terapêuticos de pessoas com estomia
}

Redes de tejido: itinerarios terapéuticos de personas con ostomia

Antonio Dean Barbosa Marques ${ }^{1 *}$, Ezequias Alexandre da Silva², Samara Aurélio Sales Vidal2, Thereza Maria Magalhães Moreira', Virna Ribeiro Feitosa Cestari', Raquel Sampaio Florêncio ${ }^{1}$

ORCID IDS

Marques ADB (D) https://orcid.org/0000-0001-8969-1546

Silva EA (D) https://orcid.org/0000-0002-9075-8514

Vidal SAS (D) https://orcid.org/0000-0001-8321-9320

Moreira TMM (D) https://orcid.org/0000-0003-1424-0649

Cestari VRF (D) https://orcid.org/0000-0002-7955-0894

Florêncio RS (D) https://orcid.org/0000-0003-3119-7187

\section{HOW TO CITE}

Marques ADB; Silva EA; Vidal SAS; Moreira TMM; Cestari VRF; Florêncio RS. Weaving networks: therapeutic itineraries of people with ostomy. ESTIMA, Braz. J. Enterostomal Ther., 2020, 18: e2120. https://doi.org/10.30886/estima.v18.909_IN

\begin{abstract}
Objective: To describe the therapeutic itinerary of people with an ostomy in search of specialized care. Method: exploratory, descriptive study with a qualitative approach, with ten people with ostomy treated at the Ostomy Care Service (Serviço de Atenção à Saúde da Pessoa Ostomizada), from August to November 2017. Reconstitution took place through semi-structured interviews, registration in a field diary and consultation with records of specialized health services, and processed by the software Interface de R pour les Analyses Multidimensionnelles de Texte et de Questionnaires. Results: the therapeutic itinerary begins with the discovery of signs and symptoms, when there is access to the nearest health services and later in search of specialized services. Marked by formal connections and supported by interrelated subsystems. The trajectories of search, production, health transport and health care management undertaken by individuals, families and informal groups express different paths and movements in the phase that precedes specialized care. Conclusion: the knowledge apprehended by the speeches enables the identification of basic needs presented by this clientele, facilities and barriers encountered in the course undertaken to obtain an adequate therapeutic plan.
\end{abstract}

DESCRIPTORS: Stomatherapy; Stoma; Patient acceptance of health care; Access to health services; Health care.

\footnotetext{
1. Universidade Estadual do Ceará - Departamento de Enfermagem - Programa de Pós-Graduação em Cuidados Clínicos em Enfermagem e Saúde - Fortaleza (CE), Brazil.

2. Faculdade Princesa do Oeste - Departamento de Enfermagem - Curso de Graduação em Enfermagem - Crateús (CE), Brazil.

*Correspondence author: antonio-dean@hotmail.com

Received: Jun. 26, 2020 | Accepted: Aug. 26, 2020
} 


\section{RESUMO}

Objetivo: descrever o itinerário terapêutico de pessoas com estomia em busca de cuidados especializados. Método: estudo exploratório, descritivo, com abordagem qualitativa, com dez pessoas com estomia atendidas no Serviço de Atenção à Saúde da Pessoa Ostomizada, de agosto a novembro de 2017. A reconstituição se deu por meio de entrevistas semiestruturadas, registro em diário de campo e consulta aos prontuários dos serviços de saúde especializados, e processadas pelo software Interface de R pour les Analyses Multidimensionnelles de Texte et de Questionnaires. Resultados: o itinerário terapêutico tem início com a descoberta dos sinais e sintomas, quando há acesso aos serviços de saúde mais próximos e a posteriori em busca de serviço especializado. Marcado por conexões formais e sustentados por subsistemas inter-relacionados. As trajetórias de busca, produção, transporte sanitário e gerenciamento do cuidado para saúde, empreendidos por pessoas, famílias e grupos informais expressam percursos e movimentos distintos na fase que antecede ao atendimento especializado. Conclusão: o conhecimento apreendido pelos discursos possibilita a identificação de necessidades básicas apresentadas por essa clientela, facilidades e barreiras encontradas no percurso empreendido para obter um plano terapêutico adequado.

DESCRITORES: Estomaterapia; Estomia; Aceitação pelo paciente de cuidados de saúde; Acesso aos serviços de saúde; Atenção à saúde.

\section{RESUMEN}

Objetivo: Describir el itinerario terapéutico de las personas con ostomía en busca de atención especializada. Método: Estudio exploratorio descriptivo, con un enfoque cualitativo, con diez personas con ostomía tratadas en el Servicio de Cuidado de Ostomía, de agosto a noviembre de 2017. La reconstitución se realizó mediante entrevistas semiestructuradas, registro en un diario de campo y consulta. A los registros de servicios de salud especializados, procesados por el software Interface de R pour les Analyzes Multidimensionnelles de Texteset et de Questionnaires. Resultados: El itinerario terapéutico comienza con el descubrimiento de signos y síntomas, cuando hay acceso a los servicios de salud más cercanos y a posteriori en busca de servicios especializados. Marcado por conexiones formales, respaldado por subsistemas interrelacionados. Las trayectorias de búsqueda, producción, transporte de salud y gestión de la atención de salud, emprendidas por personas, familias y grupos informales, expresan diferentes caminos y movimientos en la fase que precede a la atención especializada. Conclusión: El conocimiento aprehendido por los discursos permite identificar las necesidades básicas presentadas por esta clientela, las instalaciones y las barreras encontradas en el curso realizado, a fin de obtener un plan terapéutico adecuado.

DESCRIPTORES: Estomaterapia; Estoma; Aceptación del paciente de atención médica; Acceso a servicios de salud; Cuidado de la salud.

\section{INTRODUCTION}

The provision of care to users of health services must strive for comprehensive care. This becomes feasible when attention is given in a network. Therefore, each service must be rethought as an essential element, a station in the circuit that each person travels to obtain the integrality they need ${ }^{1}$.

However, fragmented systems are predominant, separate and without interlocution between services, such as primary care with secondary or tertiary care. In turn, integrated systems constitute the Health Care Network (Rede de Atenção à Saúde) and excel in coordinated deputies of units to provide constant and comprehensive assistance to the established population ${ }^{2}$. Although the relevance of referral and counter-referral mechanisms is conjectured, their agreements are considered, in order to reorganize the work processes in relation to Comprehensive Health Care Lines $^{3}$. Thus, providing access to all technological resources that the user needs, integrating preventive, curative and rehabilitation actions, carried out by assistance flows as if it were a graphic representation of the itinerary within the network ${ }^{4}$.

In an attempt to break with the fragmentation and discontinuity of care and management in health regions and aiming at improving the political-institutional functioning of the Unified Health System (Sistema Único de Saúde -SUS) to ensure the user with the set of actions and services he needs effectively and efficiently, the Health Care Network was created as a strategy through the Ordinance No. 4,279, of December 30, $2010^{5}$.

It stands out among the networks, the Care Network for People with Disabilities, which articulates points of health care for people with temporary or permanent disabilities, in progressive, regressive or stable forms, being intermittent or continuous, within the scope of the Unified Health System, in order to start early rehabilitation and disability prevention actions ${ }^{6}$.

Among people with physical disabilities, the individual with an ostomy stands out. The historicity of Public Health Policies in health care for people with ostomy has undergone several transformations over time in the world and in Brazil. 
Among the legal milestones, in 2009, the publication of ordinance no. 400 stands out, in which the National Guidelines for the Attention to Health of Ostomized People were established within the scope of the Unified Health System and the creation of the Health Care Service for the Ostomy Person ${ }^{7}$ and Normative Resolution No. 325 in the field of supplementary healthr'.

It is noteworthy that although the term "ostomy" does not exist in the Portuguese language, it remains when it comes to public policies. In this study we adopted the term stoma.

The Service of Attention to the Health of the Ostomy Person aims to carry out actions to promote self-care, prevent and treat complications in ostomies, supply of collecting equipment and protection and safety adjuvants and training of professionals ${ }^{7,9}$.

In line with the national guidelines established by the Ministry of Health, in the state of Ceará was implemented in 2016 through the Health Department, located in Fortaleza, Ceará, Brazil. This trains people with ostomy for self-care, treatment and rehabilitation, distributes collecting equipment and adjuvant devices, in addition to providing assistance to a multidisciplinary team and having a stoma reversal flow $^{10}$.

The expressive increase of people with ostomy in the state, with a monthly average of 60 new $\operatorname{cases}^{10}$, and the territorial extension of the state, with municipalities far from the capital, makes it essential to know the path of these patients in search of care. This knowledge can provide more unique and inclusive health promotion activities. The studies of the therapeutic itineraries make it possible to identify the path traveled - with regard to the formal flow. In addition to revealing the choices, access to specialized care and the social network in which the person takes part.

The study becomes relevant because it is part of the National Agenda for Health Research Priorities with regard to the axis: evaluation of policies, programs and services; sub-item: accessibility to health services ${ }^{11}$.In view of the above, the following guiding question emerged: what are the paths taken by the person with a stoma to reach the specialized service?

\section{OBJECTIVE}

Describe the therapeutic itinerary of people with an ostomy in search of specialized care.

\section{METHODS}

Exploratory, descriptive study with a qualitative approach. The study was carried out in the municipality of Crateús, Ceará, Brazil, from August to November 2017.

Twenty three adult persons registered in the Program belonging to the municipality of Crateús were identified. Due to the absence of telephone numbers in the registration of some patients, 13 were contacted via telephone and agreed to participate in the study after clarifying the purpose and method of the study. During the face-to-face contact, three people asked to give up, claiming that they did not have time to conduct the interview (s).

Thus, ten people with ostomy, living in Crateús and being monitored by the Health Care Program for the Ostomy Person in Ceará, participated in the study. The sample size was delimited by the discursive occurrence of the statements ${ }^{12}$. The following inclusion criteria were adopted: age over 18 years, living in Crateús, having an intestinal or urinary ostomy and being accompanied by the program. People with cognitive impairment that could limit participation in the research because they could not understand the interview were excluded.

For data collection, two instruments were used. The first was a questionnaire with closed questions about sociodemographic and clinical variables (sex, age, marital status, type of stoma, time spent with the stoma, stoma etiology and personal income). The second instrument was a semi-structured interview script, based on the literature about the theme and professional experience with the target audience, composed of questions that identified participants and sub-items in the form of triggering questions, about life before and after the construction of the ostomy and the "care production line (s)" (care continuum).

Participants were approached via telephone call and a day, time and place of their choice was scheduled for the application of the interview, according to availability. The interviews were recorded on a smartphone device - offline mode, containing a digital recorder application.

In-depth interviews were carried out with the participants, notes in a field diary and consultation of the medical records of the health services, forming the central empirical material from which ten narratives were constructed, which express the experience of the search for care.

In addition, a field diary was used to record relevant aspects observed during the interview, aiming to portray 
the subjects and reconstruct the dialogue. In order to guarantee anonymity to the participants whose therapeutic itineraries were analyzed, the letter "D" was used for the interviewee, followed by an Arabic numeral after the interviews were conducted.

It is noteworthy that for some participants, two to three face-to-face interviews were carried out, in addition to telephone contacts and conversations with family members in an attempt to complement the necessary information. In a complementary manner, to help compose the therapeutic itinerary, the patient's medical record was also consulted, based on the identification of the services where the user went to access the specialized service.

The interviews were transcribed in full to the LibreOffice program, submitted to refined data to exclude vocabulary repetitions, grouping of words by semantic approximation and dictionary composition. The corpus was elaborated and then the similarity analysis was performed with the processing by the software Interface de $R$ pour les Analyses Multidimensionnelles de Texte et de Questionnaires (IRaMuTeQ). It is a free program, which is anchored in the $\mathrm{R}$ software and favors different forms of statistical analysis in relation to the textual corpus and on tables of individuals by words ${ }^{13}$. It should be noted that the data were contrasted in the light of the literature on the subject.

The study complied with Resolution 466/2012 of the National Health Council and was submitted, analyzed and approved by the Research Ethics Committee, under opinion number 2,254,593. This study followed the steps recommended by the Consolidated criteria for reporting qualitative research (COREQ).

\section{RESULTS}

Ten people with an ostomy participated, with a predominance of females (80.0\%), aged between 18 and 92 years old, average age of 61.2 years. In the characterization of marital status, there was dominance of widowers and singles, both with $40.0 \%$; and $70.0 \%$ of the stomas were of the colostomy type resulting from cancer. Most of the participants $(60.0 \%)$ had an income of one minimum wage ( $\mathrm{R} \$ 937.00)$, resulting only from the sickness benefit of their new life condition, as shown in Table 1.

Figure 1 reconstructs the therapeutic itineraries covered.

Table 1. Characterization of study participants. Crateús (CE), Brazil - 2017.

\begin{tabular}{|c|c|c|c|c|c|c|c|}
\hline D & Sex & Age & $\begin{array}{l}\text { Marital } \\
\text { Status }\end{array}$ & $\begin{array}{l}\text { Stoma } \\
\text { type }\end{array}$ & $\begin{array}{l}\text { Living time } \\
\text { (years) }\end{array}$ & $\begin{array}{l}\text { Etiology of } \\
\text { ostomy }\end{array}$ & $\begin{array}{c}\text { Personal } \\
\text { income (MW) }\end{array}$ \\
\hline D1 & M & 42 & Single & Colostomy & 5 & Fournier syndrome & 1 \\
\hline D2 & F & 62 & Single & $\begin{array}{c}\text { Colostomy and } \\
\text { urostomy }\end{array}$ & 10 & Rectal cancer & 1 \\
\hline D3 & M & 22 & Married & Ileostomy & 0.6 & Firearm drilling & 1 \\
\hline D4 & $\mathrm{F}$ & 67 & Married & Ileostomy & 0.6 & Colon Cancer & 1 \\
\hline D5 & $\mathrm{F}$ & 92 & Widowed & $\begin{array}{c}\text { Colostomy and } \\
\text { urostomy }\end{array}$ & 5 & Femoral hernia & 2 \\
\hline D6 & F & 63 & Single & Colostomy & 1 & Colorectal cancer & 1 \\
\hline D7 & F & 18 & Single & Colostomy & 18 & Anorectal anomaly & 1 \\
\hline D8 & F & 76 & Widowed & Colostomy & 0.6 & Colorectal cancer & 2 \\
\hline D9 & F & 80 & Widowed & Colostomy & 10 & Colorectal cancer & 2 \\
\hline D10 & $\mathrm{F}$ & 90 & Widowed & Colostomy & 4 & $\begin{array}{c}\text { Perforated } \\
\text { diverticulitis }\end{array}$ & 2 \\
\hline
\end{tabular}




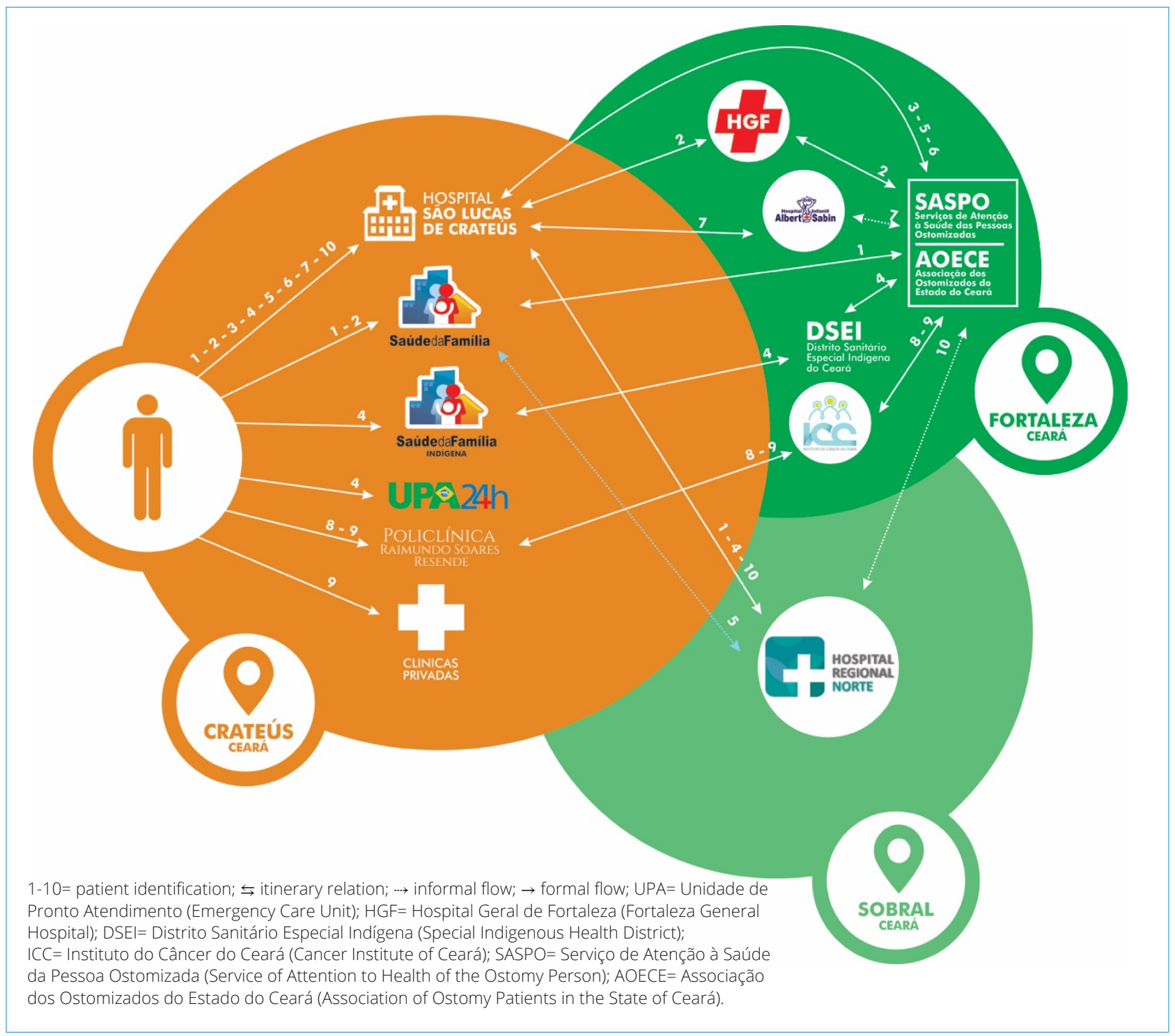

Figure 1. Therapeutic itineraries for people with ostomy. Crateús (CE), Brazil - 2017.

For a better understanding of the flow, continuous tracing is understood as a relation, dotted tracing as an informal flow and an arrow as a formal flow. Crateús, state scenario with its health care services at different levels of complexity, municipality of Sobral (Macroregion) and Fortaleza, capital of the state, home of the Ostomy Program and other health services.

It is noteworthy that the Association of Ostomy Patients of the State of Ceará was responsible until the end of 2015 for the provision of bags and care for people with an ostomy, and in 2016 this attention was carried out by the Health Department of the State of Ceará, with the creation of the Service of Attention to Health of the Ostomy Person.

In short, the paths taken in search of specialized care begin with the appearance of signs and symptoms of diseases, accidents and / or health problems, with priority access to the nearest health services that promote immediate relief from their complaints, such as general health clinics, specialized public and private care and urgent and emergency care services. When these cannot be resolved, they are better investigated during the hospitalization process (local hospital and specialized hospitals agreed) and to improve the clinical condition, the need for surgery and the building of a stoma.

Driven by the continuous need for specialized care and the use of collecting and adjuvant equipment, they seek access to the specialized service (Service of Attention to Health of the Ostomy Person), mostly by formal flow, referral / counter-referral system.

Figure 2 presents the similarity analysis, which generated a semantic range of words most evoked in the narratives, 
grouped in central and peripheral areas, allowing a better understanding of the therapeutic itinerary. It stands out as a central term "doctor", strongly surrounded by peripheral words “well”, "a lot", "Fortaleza”, "surgery” and "feel”. Thus, the paths outlined here are established through a reference system from the "doctor" to the "health secretary" of the municipality (reception and distribution of cases) and, consequently, referral to the specialized service - Service of Attention to Health of the Ostomy Person in the capital of the state "Fortaleza".

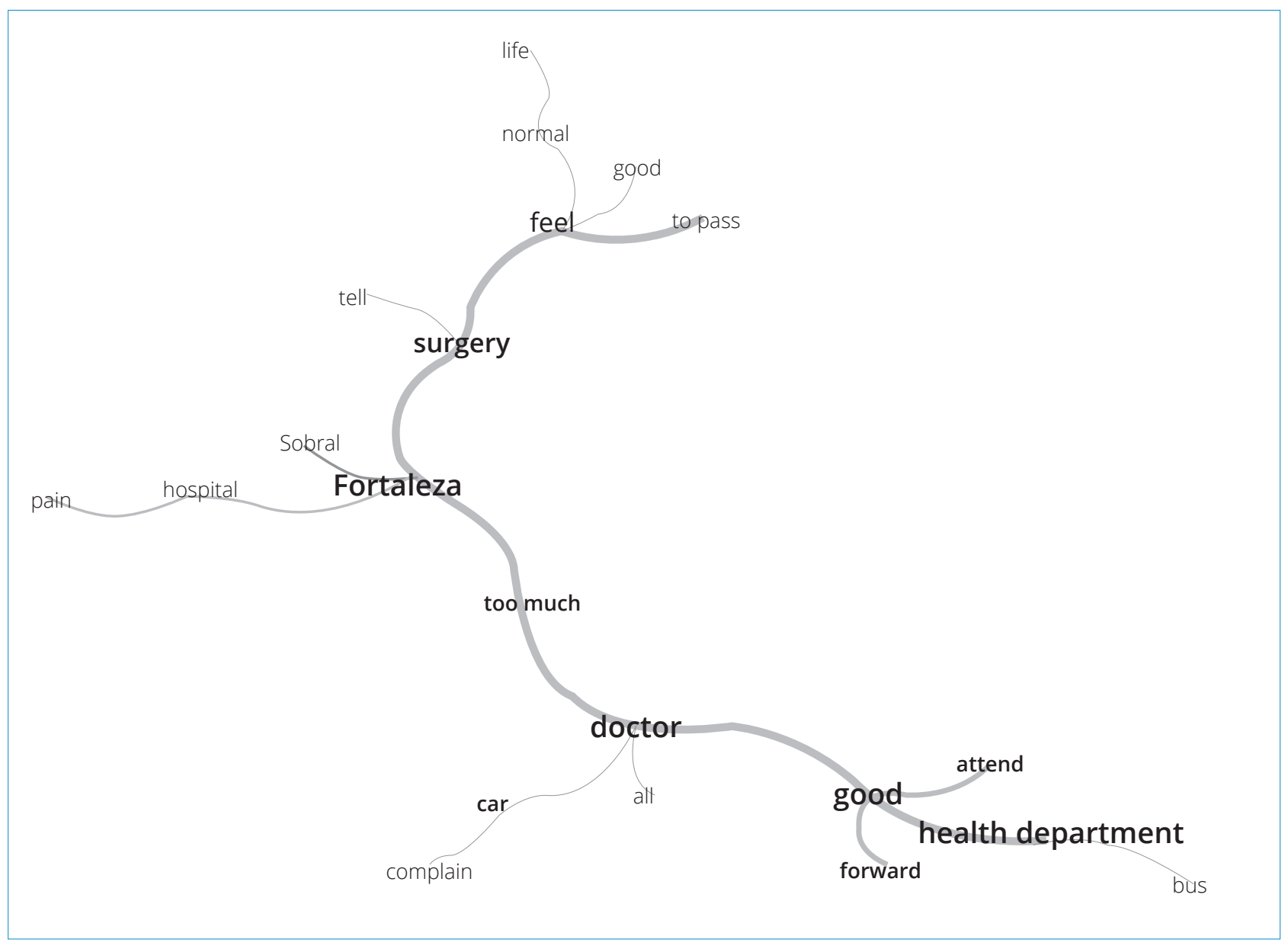

Figure 2. Similarity analysis between words. Crateús (CE), Brazil - 2017.

The symptoms are marked by gastrointestinal manifestations associated with severe pain. However, it is not something linear, a process with different moments, which begins with the perception that something different is happening in your body, according to the following statements:

I felt a thunderstorm in my belly, a lot of pain when evacuating and blood in my stool for a long time. I looked for the Family Health Program for Indigenous People, I took some medication, but it didn't improve. Every time my stomach was stuck, I went to the emergency room or the hospital to wash. I did this until the doctor at the post found it strange and ordered some tests. (D4)
At first, I had a lot of pain in my belly. My belly started to grow, to get stuffed and I spent days and days without going to the bathroom. I drank tea, everything the people taught me, but it didn't work out, so I decided to go to the health center.(D6)

I was always constipated, I felt a lot of pain, belching, itching and my body was all red. I paid for an appointment because there was no doctor at the public clinic and I was asked to have an ultrasound, but I had no money to pay. A friend got me to do it at the polyclinic. (D9)

The narrative of D1, D3 and D7 is peculiar, as the genesis of the ostomy does not result from colorectal cancer like the others: 
I went to sleep well at night and when I woke up I had a blister that turned into a wound and, in a few days, I ended up in the hospital. The wound increased so much that it took my private parts and they got rotten (crying). I don't even like to remember that. I thought I was going to die. (D1)

I got involved with some 'things' and when I tried to get out of it, I took five shots, three in the belly, one in the arm and one in the thigh. I was very lucky.(D3)

My case is different, because I grew up with it (pointing to the bag), so it's normal for me. (D7)

The path taken by people with an ostomy in the search for diagnosis and treatment begins with the appearance of signs and symptoms and the search for diagnosis with consultations and tests. With the confirmation of the diagnosis, the performance of surgery, chemotherapy / radiotherapy and the impacts of this treatment on the lives of people with ostomy and their experiences and relationships with the specialized service, thus the movements in the therapeutic itinerary took place through formal, informal and popular health systems:

PSF (Familiar Health Clinic) colleagues. (D1)

The doctor. (D2)

Nobody reffered me, I was hospitalized because of the infection and the doctor thought it was better to have the surgery, so as not to cause more infections. (D3)

I was referred from Sobral, first I was in Sobral, I went to Fortaleza, I started chemotherapy. (D4)

The doctor. (D7)

I was sent from Sobral to Fortaleza. (D10)

The neighbor took me to the hospital, and I was referred by the doctor. (D9)

The Department referred, with a social worker. (D6)

The doctor. (D5)

The paths and (dis) paths in search of specialized services by the interviewees, took place in the most varied ways:

[[...] often on a bicycle, when I travel to Sobral or Fortaleza I take the bus. (D1)

We go by bus. (D2)
The health department staff made the appointment [... for Fortaleza. (D3)

I walked a lot! I was from the hospital, emergency department and health clinic, until the hospital here (Crateús) sent me to Sobral by ambulance. In Sobral, I had another surgery to put another bag. Then I was sent to Fortaleza to register and receive the bags there. Everything arranged by the indigenous people. (D4)

By the Gentil Barreiras'bus. (D6)

Through Gentil Barreiras, we go by the City Hall car. (D7)

I took the bus at Gentil Barreiras. (D5)

I went by my own car. (D8)

I took the referral from Gentil Barreiras to Fortaleza.(D9)

I was sent from Sobral to Fortaleza with the doctor's papers for the association. Then I went to the clinic (Ostomy Program). (D10)

The testimonies expressed different paths and movements in the phase that precedes specialized assistance. As well as the trajectories of search, production, health transportation and health care management, undertaken by people, families and informal groups.

\section{DISCUSSION}

From the analysis of the participants' statements, the search for an appropriate therapy emerges with the perception that something is not right, manifested by changes in physical orders that cause discomfort. At that moment, the person seeks to formalize the "diagnosis", causing the search for care and treatments. From this decision, the choices are usually those that make sense for each one, anchored in previous experiences, always provisional. At that moment there is no single path, each subject makes choices within the possibilities that they visualize, there are multiple and distinct paths ${ }^{14}$.

The trajectory traveled begins with the appearance of the first signs and symptoms until the diagnosis and referral to the specialized treatment unit. Some directly access urgent and emergency services, whether in emergency units or hospitals. Sometimes without quick resolution and sometimes with diagnosis and referral to a referral unit ${ }^{15}$. 
With regard to the clinical course of diseases, especially on cancers, it is interwoven from unspecific signs and symptoms, sometimes devalued by both the patient and health professionals, to the detriment of sociocultural or organizational barriers, causing delay in diagnosis ${ }^{16}$.

It is noteworthy that the search, as well as the late diagnosis of the disease, takes a long time to start treatment and the difficulty of offering care and adequate treatment are determining factors for the worsening of the disease and mortality, pointing out weakness in the service network ${ }^{17}$.

The urgency and emergency services act in meeting the acute demands in a more agile and concentrated way, since the complaint of biological nature can represent a health risk. Another portion accesses these due to unavailability of resources in primary health care or other difficulties in accessing primary care services ${ }^{16}$.

The different levels of health care must be trained and able to meet the needs of the population and promote comprehensive care. Its efficient performance must include the ability to recognize the signs and symptoms, thus contributing to early suspicion, with proper referral to the specialist doctor who will carry out the diagnostic confirmation ${ }^{15}$.

Care systems are built by formal, regular and regulated connections between health services, composing "networks" or "lines" of care, usually designed by managers and operated daily by professionals in their actions and interactions with users, in perspective of building comprehensive care. To represent these paths and lines of care, the image of a "pyramid" was the representation historically constituted, especially due to the increasing complexity of services interconnected by formal processes of reference / counter-reference, with upward and downward flows that users should follow ${ }^{18}$.

"Access" can also be defined as "entering the system", obtaining the care deemed necessary (by professionals and / or users), in a timely and qualified manner. In other words, this category concerns accessing a place (a service, a professional, etc.), at the appropriate time (a time between trying and getting it) and getting what you need (producing a response, an act of health) ${ }^{19}$. It is worth considering, however, that the definition and qualification of what "adequate place", "adequate time" and "adequate response" means depends on who enunciates them, being, therefore, marked by dissent, disputes and conflicts ${ }^{18}$.

The "health system" is composed of three interrelated subsystems: the "informal" (family, community, network of friends, support and self-help groups), the "popular" (specialized secular or religious agents, but not legally recognized society) and the "formal" or "professional" subsystem (offered by government agents). Users and their families seek attention in the three spheres, without necessarily following the same direction or hierarchy, tracing therapeutic itineraries in particular ways ${ }^{20}$.

Such paths taken in the search for solutions to health problems are, in general, little known or relegated to a secondary level, not being a priority theme during professional training in health and, also, little present in the concerns of researchers, managers or formulators of policies. However, they can offer an opportunity to understand the complexity and multiplicity of movements and lines drawn in daily life by users, to analyze their characteristics or attributes that give new meanings to access, use and quality of health services from the perspective of users ${ }^{21}$.

The testimonies subsidized the design of diagrams or "care maps" that were individually configured and, later, were overlaid, seeking an "analytical generalization" for the questions on screen. The "care maps" are formed by the set of access and care points that each person produces based on their needs and experiences, at different times in life and in the processes of illness.

In this context, primary care, being close to the user and meeting the main health needs, is configured as the ordering of care. It is common in the itinerary constant pilgrimages by the Health Care Network and health services in search of care and resolution. Socioeconomic factors, vulnerability in access to these services and impairment of the bond between families and professionals have an impact on care and the search for specialized care ${ }^{20,22-23}$.

However, there is another dimension of the constitution of a "health care network" that escapes the formal logic of health system managers and that configures another way for the user to access, use and assign meanings of quality to the health services that they use in situations of illness. These constitute the real movements of users and the ways in which they build their "unique therapeutic itineraries" in the health system, an issue understood in the scope of this research ${ }^{3}$.

It is known that the organization of a network of health services must excel in a flow centered on the peculiar needs of a specific social group. Based on this 
prism and considering the person with an ostomy as a unique and singular being, it is essential to develop public health policies that continuously seek to improve and (re) organize the care demands for health promotion ${ }^{22}$.

The limited number of participants stands out as a limiting factor for this study. This fact did not allow the application of other analysis alternatives by IRaMuTeQ to the detriment of the size of the textual corpus.

\section{CONCLUSION}

The path taken by people with a stoma to the specialized service occurs with the appearance of signs and symptoms, the search for diagnosis, treatment (primary care, specialized services and outpatients) and, consequently, surgical intervention (hospitals), with access marked by formal connections, supported by interrelated subsystems: the "informal", the "popular" and the "formal" subsystem.

Understanding how lines of care are produced for people with stomas provide the identification of basic needs presented by this clientele, (re) knowing the facilities and barriers encountered in the course undertaken until an accurate diagnosis is obtained and the appropriate therapeutic plan is implemented / specialized and everyday social relations in this interstice.

\section{AUTHORS “CONTRIBUTION}

Conceptualization: Marques ADB; Methodology: Marques ADB, Florêncio RS e Cestari VRF; Investigation: Silva EA, Vidal SAS e Marques ADB; Writing - First version: Marques ADB; Recursos: Marques ADB, Silva EA e Vidal SAS; Supervision: Moreira TMM.

\section{REFERENCES}

1. Silveira CB, Costa LSP, Jorge MSB. Redes de atenção à saúde como produtoras de cuidado em saúde mental: uma análise reflexiva. Rev Port Enferm Saúde Mental 2018 jun;19:61-70. https://doi.org/10.19131/rpesm.0203

2. Santos L. Região de saúde e suas redes de atenção: modelo organizativo-sistêmico do SUS. Cien Saude Colet 2017 abr;22(4):1281-9. https://doi.org/10.1590/141381232017224.26392016

3. Silva NEK, Sancho LG, Figueiredo WS. Entre fluxos e projetos terapêuticos: revisitando as noções de linha do cuidado em saúde e itinerários terapêuticos. Cien Saude Colet 2016 mar; 21(3):843-52. https://doi.org/10.1590/141381232015213.08572015

4. Carnut L. Cuidado, integralidade e atenção primária: articulação essencial para refletir sobre o setor saúde no Brasil. Saúde Debate 2017 dez;41(115):1177-86. https://doi. org/10.1590/0103-1104201711515

5. Portaria n. 4.279 de 30 de dezembro de 2010 (BR). Estabelece diretrizes para a organização da Rede de Atenção à Saúde no âmbito do Sistema Único de Saúde (SUS). Diário Oficial da União [periódico na internet], Brasília (DF). 30 dez 2010 [cited 13 may 2019]. Available at: https:// conselho.saude.gov.br/ultimas_noticias/2011/img/07_jan_ portaria4279_301210.pdf

6. Portaria n. 793, de 24 de abril de 2012 (BR). Institui a rede de cuidados à pessoa com deficiência no âmbito do Sistema Único de Saúde. Diário Oficial da União [periódico na internet], Brasília (DF). 24 abr 2012. [cited 13 may 2019]. Available at: https://bvsms.saude.gov.br/bvs/saudelegis/ gm/2012/prt0793_24_04_2012.html

7. Portaria n. 400, de 16 de novembro de 2009 (BR). Considerando a política nacional de saúde da pessoa com deficiência, instituída pela Portaria n. 1.060/GM, de 05 de junho de 2002. Diário Oficial da União [periódico na internet], Brasília (DF). 18 nov 2009 [cited 13 may 2019]. Available at: http://bvsms.saude.gov.br/bvs/saudelegis/ sas/2009/prt0400_16_11_2009.html

8. Resolução normativa - RN n. 325 de 18 de abril de 2013 (BR). Altera a Resolução Normativa - RN n. 211, de 11 de janeiro de 2010, que dispõe sobre o Rol de Procedimentos e Eventos em Saúde no âmbito da Saúde Suplementar, para regulamentar o fornecimento de bolsas de colostomia, ileostomia e urostomia, sonda vesical de demora e coletor de urina com conector, de que trata art. 10-B da Lei n 9.656, de 1998. Diário Oficial da União [periódico na internet], Brasília (DF). 18 abr 2013 [cited 13 may 2019]. Available at: https://bvsms.saude.gov.br/bvs/saudelegis/ans/2013/ res0325_18_04_2013.html

9. Moraes JT. Serviços de atenção ao estomizado: análise diagnóstica no Estado de Minas Gerais, Brasil. Cad Saúde Colet 2014 jan/mar;22(1):101-8. https://doi. org/10.1590/1414-462X201400010015

10. Secretaria da Saúde do Estado do Ceará. Programa comemora Dia dos Ostomizados com crescimento de 63\% 
[Internet]. 2017 [cited 2019 May 13]. Available at: https:// www.ceara.gov.br/2017/11/16/programa-comemora-diados-ostomizados-com-crescimento-de-63/

11. Ministério da Saúde (BR). Agenda nacional de prioridades de pesquisa em saúde. $2^{\text {a }}$ ed. Brasília (DF): Ministério da Saúde; 2015.

12. Minayo MCS. Amostragem e saturação em pesquisa qualitativa: consensos e controvérsias. Rev Pesqui Qual [Internet]. 2017 abr; [cited 2019 may 13]; 5(7):1-12. Available at: https://editora.sepq.org.br/index.php/rpq/ article/view/82

13. Souza MAR, Wall ML, Thuler ACMC, Lowen IMV, Peres AM. O uso do software IRAMUTEQ naanálise de dados em pesquisas qualitativas. Rev Esc Enferm USP 2018 out; 52:e03353. https://doi.org/10.1590/s1980-220×2017015003353

14. Brustolin A, Ferretti F. Itinerário terapêutico de idosos sobreviventes ao câncer. Acta Paul Enferm 2017 jan/ fev;30(1):47-59. https://doi.org/10.1590/1982-0194201700008

15. Lima BC, Silva LF, Góes FGB, Ribeiro MTS, Alves LL. O itinerário terapêutico de famílias de crianças com câncer: dificuldades encontradas neste percurso. Rev. Gaúcha Enferm 2018 out;39:e20180004. https://doi.org/10.1590/19831447.2018 .20180004

16. Souza KA, Souza SR, Tocantins FR, Freitas TF, Pacheco PQC. O itinerário terapêutico do paciente em tratamento oncológico: implicações para a prática de enfermagem. Cienc Cuid Saude 2016 abr/jun;15(2):259-67. https://doi. org/10.4025/cienccuidsaude.v15i2.29896

17. Foletto EF, Jackisch SE, Dotto ML, Severo C, Pappen E, Valim ARM et al. Therapeutic itinerary of colorectal cancer patients treated in the state of Rio Grande do Sul. J Coloproctol 2016 abr/jun;36(2):91-6. https://doi.org/10.1016/j.jcol.2016.03.008

18. Lazarino MSA, Silva TL, Dias EC. Apoio matricial como estratégia para o fortalecimento da saúde do trabalhador na atenção básica. Rev bras saúde ocup 2019 jun;44:e23. https://doi.org/10.1590/2317-6369000009318

19. Souza FF, Zambenedetti G. Percursos de cuidado: pistas sobre itinerários terapêuticos em saúde mental. Tempus Actas Saúde Colet 2018 ago;11(4):105-22. https://doi. org/10.18569/tempus.v11i4.2485

20. Siqueira SMC, Jesus VS, Camargo CL. Itinerário terapêutico em situações de urgência e emergência pediátrica em uma comunidade quilombola. Ciênc Saúde Coletiva 2016 jan; 21(1):179-89. https://doi.org/10.1590/141381232015211.20472014

21. Silva JG, Branco JGO, Vieira LJES, Brilhante AVM, Silva RM. Direitos sexuais e reprodutivos de mulheres em situação de violência sexual: o que dizem gestores, profissionais e usuárias dos serviços de referência? Saude soc 2019 abr/jun;28(2):187200. https://doi.org/10.1590/s0104-12902019180309

22. Luz RO, Pieszak GM, Arrué AM, Gomes GC, Neves ET, Rodrigues AP. Itinerário terapêutico de famílias de crianças com necessidades especiais de saúde. Rev Rene 2019; 20:e33937. https://doi.org/10.15253/21756783.20192033937

23. Figueiredo PA, Alvim NAT. Diretrizes para um programa de atenção integral a pacientes estomizados e familiares: uma proposta de enfermagem. Rev Latino-Am Enfermagem 2016; 24:e2694. https://doi.org/10.1590/1518-8345.0507.2694 